\title{
PEMANFAATAN SISTEM INFORMASI PADA PENGOLAHAN DATA POSYANDU DI RW. 020 DESA RANCAMANYAR KABUPATEN BANDUNG
}

\author{
Asye Rachmawaty, S.T., M.M. \\ Dosen Program Studi Manajemen Informatika \\ Politeknik LP3I Bandung \\ e-mail: asyerachmawaty@gmail.com
}

\begin{abstract}
Abstrak : Posyandu sangat diperlukan dalam mendekatkan upaya promotif dan preventif kepada masyarakat, utamanya terkait dengan upaya peningkatan status gizi masyarakat serta upaya kesehatan ibu dan anak. Peran dan dukungan Pemerintah kepada Posyandu melalui Puskesmas sangat penting untuk memfasilitasi pelaksanaan berbagai kegiatan kesehatan di Posyandu.

Posyandu di Desa Rancamanyar Kecamatan Baleendah, yaitu Posyandu Sakura masih sangat memerlukan penataan dalam berbagai bidang seperti pembinaan kader, kelengkapan sarana prasarana, pengolahan data dan informasi, pelayanan dan promosi, serta pengelolaan keuangan. Dalam hal pengolahan data dan informasi guna pengembangan Posyandu tersebut, diperlukan sebuah sistem informasi Posyandu.

Metode yang digunakan dalam penelitian ini adalah Action Research (Penelitian Tindakan). Adapun teknik pengumpulan datanya melalui wawancara dan observasi. Jenis luaran yang diharapkan adalah model sistem informasi Posyandu dan Jurnal Ilmiah.
\end{abstract}

Kata Kunci: Sistem Informasi Posyandu, Pengolahan Data.

\section{Pendahuluan}

Kesehatan merupakan hak azasi (UUD 1945, pasal $28 \mathrm{H}$ ayat 1 dan UU No. 36 Tahun 2009 tentang Kesehatan) dan sekaligus sebagai investasi, sehingga perlu diupayakan, diperjuangkan dan ditingkatkan oleh setiap individu dan oleh seluruh komponen bangsa, agar masyarakat dapat menikmati hidup sehat, dan pada akhirnya dapat mewujudkan derajat kesehatan masyarakat yang optimal. Hal ini perlu dilakukan karena kesehatan bukanlah tanggung jawab pemerintah saja, namun merupakan tanggung jawab bersama pemerintah dan masyarakat, termasuk swasta. (Kemenkes RI, 2011:1)

Posyandu merupakan salah satu bentuk Upaya Kesehatan Bersumber Daya Masyarakat (UKBM) yang dikelola dan diselenggarakan dari, oleh, untuk dan bersama masyarakat dalam penyelenggaraan pembangunan kesehatan, guna 
memberdayakan masyarakat dan memberikan kemudahan kepada masyarakat dalam memperoleh pelayanan kesehatan dasar, utamanya untuk mempercepat penurunan angka kematian ibu dan bayi. (Kemenkes RI, 2011:2)

Jumlah Posyandu di Kabupaten Bandung sampai akhir tahun 2012 sebanyak 4.150 posyandu atau dengan tingkat perkembangan posyandu melalui telah mawas diri berdasarkan jenis posyandu adalah Posyandu Pratama dengan jumlah 597 buah atau 14.38\%, Posyandu Madya sebesar 2.137 buah sekitar 51.49\%, Posyandu Purnama berjumlah 1.261 buah atau 30.38\%, sedangkan Posyandu Mandiri berjumlah 155 atau $3.75 \%$. Dengan demikian dapat terlihat bahwa baru $3.75 \%$ posyandu yang berstata mandiri sementara jumlah posyandu yang telah memiliki bangunan sendiri baru mencapai 1.131 buah, sisanya masih menumpang di rumah warga secara sukarela (data dari BPMPB). Berikut secara lengkap disajikan data mengenai kondisi jumlah Posyandu berdasarkan jenis posyandu di Kabupaten Bandung selama kurun waktu tahun 2012.

Tabel Jumlah Posyandu di Kabupaten Bandung Tahun 2012

\begin{tabular}{|l|l|l|l|}
\hline No. & Nama Posyandu & Jumlah (Buah) & Persentase (\%) \\
\hline 1 & Posyandu Pratama & 597 & 14.38 \\
\hline 2 & Posyandu Madya & 2.137 & 51.49 \\
\hline 3 & Posyandu Purnama & 1.261 & 30.38 \\
\hline 4 & Posyandu Mandiri & 155 & 3.75 \\
\hline
\end{tabular}

Sumber : BPMPD (Badan Pemberdayaan Masyarakat dan Pemerintahan Desa)

Posyandu Sakura yang ada di Kabupaten Bandung, tepatnya di RW.020 Desa Rancamanyar Kecamatan Baleendah. Posyandu tersebut termasuk kedalam Posyandu mandiri dengan keadaan jumlah anggota Posyandu 159 orang yang terdiri 10 orang ibu hamil dan 149 orang balita.

Kegiatan Posyandu setiap bulannya adalah menyelenggarakan penimbangan balita, imunisasi, pemberian vitamin, pemeriksaan kehamilan, dan sesekali mengadakan kegiatan tambahan seperti penyuluhan dari Puskesmas; lomba balita sehat; lomba mewarnai; dan pelatihan kader. Namun tingkat kesadaran masyarakat mengenai pentingnya peranan Posyandu masih harus ditingkatkan, hal ini dapat dilihat dari tingkat kunjungan anggota dalan tiga bulan terakhir seperti grafik di bawah ini:

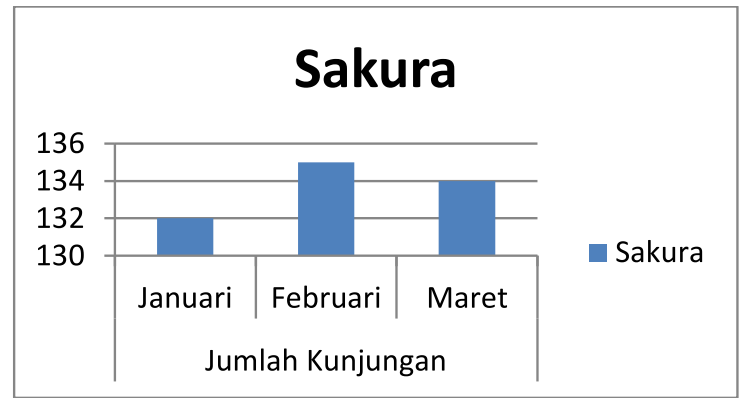

Garfik kunjungan anggota Posyandu 
Berbagai masalah yang diakibatkan kerterbatasan sarana prasarana, penyimpanan dan pengolahan data mengakibatkan kader kesulitan dalam pendataan anggota dan pembuatan laporan. Keterbatasan sarana prasarana seperti tidak adanya tempat khusus yang dijadikan kantor dan tempat pelaksanaan kegiatan Posyandu yang mengakibatkan setiap akan menyelenggarakan kegiatan, kader harus mencari tempat/lahan/halaman rumah warga yang bersedia dijadikan tempat pelaksanaan kegiatan tersebut. Data-data anggota Posyandu dan segala peralatan yang mendukung kegiatan Posyandu disimpan terpisah di beberapa kader Posyandu, sehingga pengarsipan data kurang baik.

Disamping pengarsipan data yang kurang baik, pengolahan data dan pembuatan laporan pun memakan waktu yang relatif lama dikarenakan peng-input-an data dan penyimpanan data masih dilakukan secara manual. Masih terjadinya kerangkapan dan kehilangan data yang diakibatkan hilangnya Kartu Menuju Sehat (KMS) sehingga mengharuskan pendataan ulang. Hal ini menyebabkan data/laporan menjadi tidak akurat, tidak fleksibel, tidak praktis dan sulit untuk dikerjakan. Hal ini dikarenakan kedua Posyandu tersebut belum menggunakan sistem informasi dalam melakukan pekerjaannya.

\section{Landasan Teori}

\subsection{Sistem Informasi Posyandu}

Sistem informasi adalah gabungan yang terorganisasi dari manusia, perangkat lunak, perangkat keras, jaringan komunikasi, dan sumber daya data dalam mengumpulkan, mengubah, dan menyebarkan informasi dalam organisasi. (O'Brien, 2007:45). Gondodiyoto (2007:112), menyatakan bahwa sistem informasi masih dapat didefinisikan sebagai kumpulan elemen-elemen atau sumber daya dan jaringan prosedur yang saling berkaitan secara terpadu, terintegrasi dalam suatu hubungan hierarki tertentu, dan bertujuan untuk mengolah data menjadi informasi.

Dari kedua definisi tersebut dapat disimpulkan bahwa system informasi adalah sekumpulan data olahan yang terintegrasi dan saling melengkapi informasi untuk menghasilkan suatu output yang baik. Dengan sistem informasi, pekerjaan organisasi akan lebih mudah dikarenakan semua data akan diolah dalam sebuah sistem yang terintegrasi dan informasi yang dihasilkan akan sesuai dengan kebutuhan pengguna. Kecepatan dalam bekerja dan keakuratan dalam pemberian informasi akan lebih baik dengan menggunakan sistem informasi, sehingga kinerja organisasi akan menjadi optimal.

Sistem Informasi Posyandu (SIP) adalah seperangkat alat penyusunan data dan informasi yang berkaitan dengan kegiatan, kondisi, dan perkembangan yang terjadi di setiap Posyandu. SIP adalah dari berbagai komponen kegiatan Posyandu yang menghasilkan data dan informasi tentang pelayanan terhadap tumbuh kembang anak dan pelayanan kesehatan dasar ibu dan anak yang meliputi cakupan program, kontinuitas penimbangan, hasil penimbangan, dan partisipasi masyarakat. 


\subsection{Pengolahan Data}

Menurut Jogiyanto Hartono (2006:8) data adalah bentuk yang masih mentah, belum bisa bercerita banyak, sehingga perlu diolah lebih lanjut. Data diolah melalui suatu model untuk dihasilkan informasi. Sedangkan pengolahan (processing) adalah proses data yang diolah melalui suatu model menjadi informasi, penerima kemudian menerima informasi tersebut, membuat suatu keputusan dan melakukan tindakan, yang berarti menghasilkan suatu tindakan yang lain yang akan membuat sejumlah data kembali. Data tersebut akan dtangkap sebagai input, diproses kembali lewat suatu model dan seterusnya membentuk suatu siklus. Siklus ini disebut juga dengan siklus pengolahan data (data processing cycles).

Jadi pengolahan data (data processing) dapat dikatakan sebagai susunan atau kumpulan dari hasil kegiatan pikiran dengan bantuan tenaga atau suatu peralatan, sehingga dapat menghasilkan informasi untuk mencapai tujuan tertentu.

\section{Metodologi Penelitian}

Metode pendekatan yang dilakukan dalam melaksanakan penelitian ini adalah Action Research (AR) atau penelitian tindakan, yaitu penelitian yang dilakukan secara kolaboratif oleh partisipan dalam ilmu sosial dan pendidikan untuk memperbaiki pemahaman dan pelaksanaan pekerjaannya sendiri, dan juga membawa dampak pada lingkungan di sekitarnya. (Badrun KW, 1998)

Rincian kegiatan tersebut adalah sebagai berikut:

1. Wawancara dan observasi, dilakukan oleh peneliti kepada ketua Posyandu untuk mengetahui keadaan, kegiatan, kedudukan, serta permasalahan yang dihadapi Posyandu tersebut.

2. Identifikasi masalah, yaitu tahapan awal yang dilakukan untuk mengetahui permasalahan yang terjadi melalui metode wawancara dan observasi.

3. Sosialisasi, dilakukan dengan dua tahap. Pertama untuk memberikan penjelasan tentang manfaat dan kegunaan dari sistem informasi yang akan dibangun, dan kedua untuk menjelaskan hasil perancangan sistem serta desain antarmuka untuk selanjutnya disetujuti oleh pihak Posyandu. Setelah perancangan sistem dan desain antarmuka disepakati kedua belah pihak, selanjutnya dilakukan pembangunan program aplikasi.

4. Pengumpulan data, dilakukan untuk mengetahui serta melengkapi kebutuhankebutuhan dalam perancangan sistem.

5. Menyusun basis data (Database Management System), yaitu tahapan yang dilakukan untuk menentukan data apa saja yang diperlukan dalam sistem serta kunci elemen data agar tidak redudansi; entitas dan atribut yang berhubungan dengan sistem; nilai data yang akan digunakan; pengolahan data seperti apa yang dilakukan oleh sistem; dan penentuan level abstraksi data.

6. Pembangunan Sistem Informasi, yaitu tahapan dimana rancangan basis data dan desain antarmuka direalisasikan.

7. Uji coba sistem, tahapan untuk menguji sistem informasi Posyandu yang sudah dibuat. 
8. Pelatihan, dilakukan ketika aplikasi sistem informasi sudah selesai dan siap diserahkan kepada kedua Posyandu. Pelatihan akan dilaksanakan sebanyak dua kali pertemuan, masing-masing pertemuan selama 240 menit.

\section{Hasil Penelitian dan Pembahasan \\ 4.1 Gambaran Umum}

Berdasarkan hasil wawancara dan observasi, ditemukan beberapa persoalan prioritas yang dihadapi oleh mitra dalam hal ini Posyandu Sakura, yaitu rendahnya pengelolaan data dan informasi. Posyandu Sakura memiliki intensitas keaktifan yang cukup baik, namun dalam hal pengelolaan data masih kurang tertata dengan baik. Minimnya sarana prasarana yang dimiliki Posyandu menyebabkan penyimpanan berkas-berkas kurang tertata, selain itu penyimpanan data berupa berkas sangat riskan mengalami kerusakan dan atau kehilangan. Tidak adanya sistem informasi yang berfungsi untuk mengolah data menyebabkan informasi yang dibutuhkan pengguna menjadi kurang akurat, serta dalam pengerjaannya pun membutuhkan waktu yang relatif lama. Sampai saat ini penyampaian informasi/laporan kepada desa dilakukan dengan cara tertulis oleh kader, hal ini menyebabkan data yang dilaporkan tidak menampilkan informasi mutakhir.

Dari uraian permasalahan tersebut, peneliti memberikan solusi dengan pembangunan sistem informasi Posyandu yang berguna dalam pengolahan data Posyandu serta memudahkan dalam pembuatan laporan. Sehingga dengan adanya sistem informasi Posyandu tersebut, diharapkan dapat meningkatkan kinerja Posyandu dalam hal pelayanan kesehatan. Sistem informasi ini berupa aplikasi desktop yang akan di-install-kan pada laptop Posyandu. Pengguna sistem informasi Posyandu adalah kader yang ditunjuk oleh Posyandu untuk mengoperasikan aplikasi ini. Kader yang ditunjuk adalah kader-kader yang akan mengikuti pelatihan penggunaan sistem informasi Posyandu.

\subsection{Pengumpulan Data}

Pengumpulan data yang diperlukan adalah sebagai berikut:

1. Data dasar Posyandu, terdiri atas: data dasar, indikator pelayanan, dan fasilitas

2. Data ketenagaan kader Posyandu

3. Data kegiatan pelayanan Posyandu, terdiri atas: pelayanan penimbangan, pelayanan imunisasi dan vitamin, periksa kehamilan, dan pelayanan Keluarga Berencana

4. Format pencatatan, terdiri atas: format register bayi dan balita, format register ibu hamil dan nifas, format register WUS dan PUS

5. Data Posyandu, terdiri atas: jumlah pengunjung dan jumlah kader yang hadir

6. Pelaporan, terdiri atas: laporan data kehamilan; kelahiran; dan kematian, laporan data balita dan batita, laporan hasil kegiatan Posyandu 


\subsection{Database Management System}

DBMS (DataBase Management System) adalah sistem yang secara khusus dibuat untuk memudahkan pemakai dalam mengelola basis data, dimana sistem mengijinkan penggunanya untuk membuat, mengakses, dan mengatur sebuah database. Pada pendekatan database, setiap file yang ada pada tiap departemen disimpan pada sebuah server database dengan sebutan baru, yaitu table. Lalu setiap program dapat mengakses bagian dari database sesuai kebutuhan. Berikut gambaran umum prosedur pelayanan Posyandu Sakura:

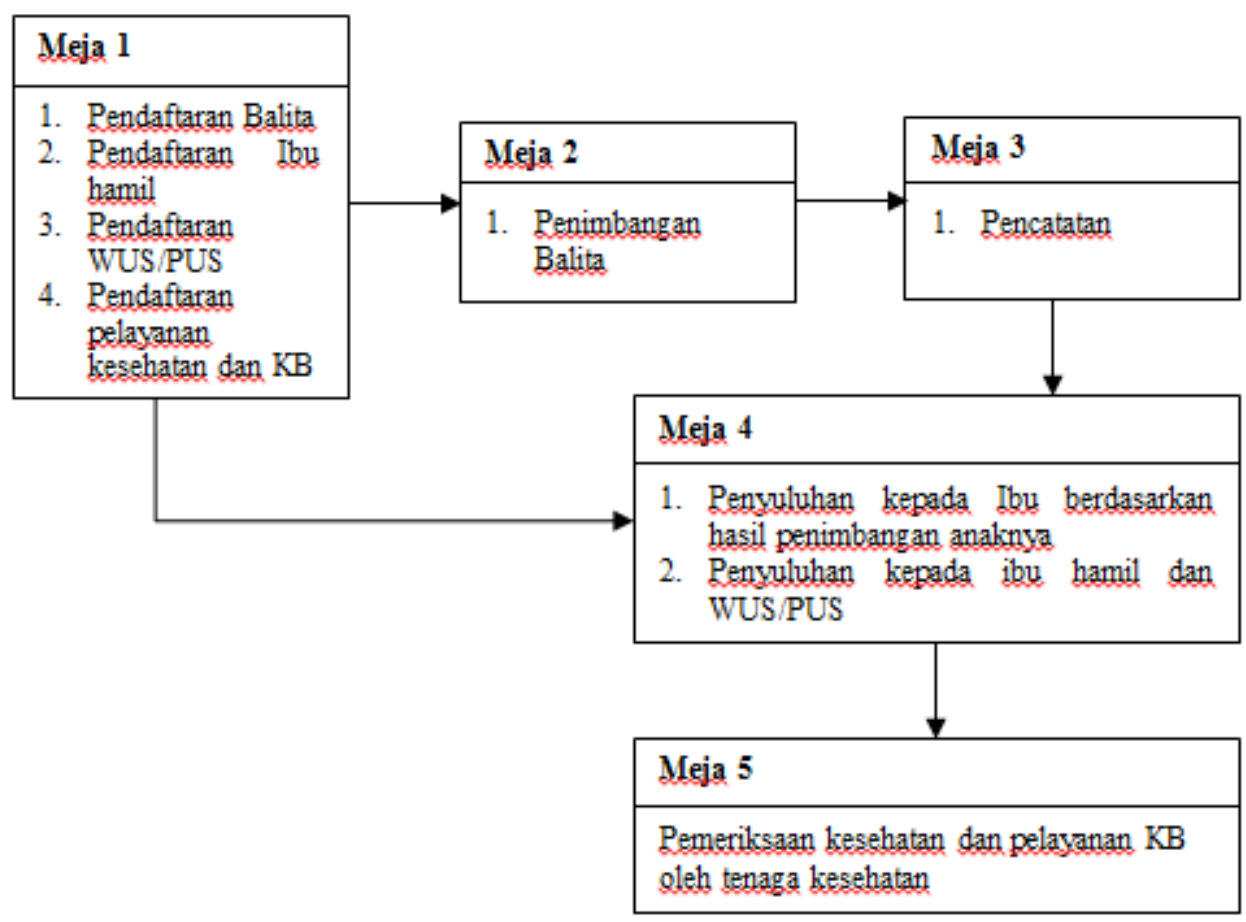

\subsection{Pembangunan Sistem Informasi}

Pembangunan Sistem Informasi berawal dari:

1. Class Diagram atau diagram kelas menggambarkan struktur sistem dari segi pendefinisian kelas-kelas yang akan dibuat untuk membangun sistem. Kelas memiliki apa yang disebut atribut dan metode atau operasi. Atribut merupakan variable-variabel yang dimiliki oleh suatu kelas, sedangkan operasi atau metode adalah fungsi-fungsi yang dimiliki oleh suatu kelas.

2. Diagram Objek menggambarkan struktur sistem dari segi penamaan objek dan jalannya objek dalam sistem. Pada diagram objek harus dipastikan semua kelas yang sudah didefinisikan pada diagram kelas harus dipakai objeknya. Karena jika tidak pendefinisian kelas itu tidak dapat dipertanggungjawabkan.

3. Diagram menggambarkan proses bisnis (alur kerja) suatu sistem informasi. Sebuah diagram yang menunjukkan suatu alur kegiatan secara berurutan. Activity Diagram digunakan untuk mendeskripsikan kegiatankegiatan dalam sebuah operasi meskipun juga dapat digunakan untuk mendeskripsikan alur 
kegiatan yang lainnya seperti use case atau suatu interaksi. Tetapi Activity Diagram tidak menunjukkan bagaimana objek berprilaku atau objek berkaloborasi dengan detail. Terdapat 6 Activity Diagram dalam Sistem Informasi Posyandu, yaitu Pengguna; Posyandu; Kegiatan; Imunisasi; Pemeriksaan; dan Laporan.

4. Sequence Diagram menggambarkan kelakuan objek pada use case diagram dengan mendeskripsikan waktu hidup objek dan message yang dikirimkan dan diterima antarobjek. Oleh karena itu banyaknya diagram sekuen yang harus digambar sebanyak pendefenisian use case yang memiliki proses tersendiri, sehingga semakin banyak use case maka semakin banyak pula diagram sekuen. Terdapat 25 Sequence Diagram pada perancangan sistem ini.

\subsection{Uji Coba Sistem}

Implementasi sistem merupakan hasil perancangan dan desain dari Sistem Informasi Posyandu yang telah dibuat. Di dalam implementasi sistem ini nantinya juga dijelaskan langkah-langkah penggunaan dari tiap-tiap menu yang ada pada aplikasi Sistem Informasi Posyandu yang terintegrasi tersebut. Di dalam implementasi tersebut terdiri dari Form Menu, Form Master, Form Kegiatan, dan Form laporan.

\subsection{Pelatihan}

Pelatihan dilakukan setelah aplikasi sistem informasi selesai diujicobakan dan telah diserahkan kepada Posyandu. Pelatihan dilaksanakan sebanyak dua kali pertemuan oleh kader yang dipilih untuk menjadi pengguna Sistem Informasi Posyandu, masing-masing pertemuan selama 240 menit.

\section{Kesimpulan}

Dari kegiatan penelitian yang telah dilakukan, maka hasilnya dapat disimpulkan sebagai berikut:

1. Kegiatan Posyandu setiap bulannya adalah menyelenggarakan penimbangan balita, imunisasi, pemberian vitamin, pemeriksaan kehamilan, dan sesekali mengadakan kegiatan tambahan seperti penyuluhan dari Puskesmas; lomba balita sehat; lomba mewarnai; dan pelatihan kader. Namun tingkat kesadaran masyarakat terhadap pentingnya kegiatan Posyandu masih perlu ditingkatkan.

2. Keterbatasan sarana prasarana seperti tidak adanya tempat khusus yang dijadikan kantor dan tempat pelaksanaan kegiatan Posyandu yang mengakibatkan setiap akan menyelenggarakan kegiatan, kader harus mencari tempat/lahan/halaman rumah warga yang bersedia dijadikan tempat pelaksanaan kegiatan tersebut. Kerterbatasan sarana prasarana, penyimpanan dan pengolahan data mengakibatkan kader kesulitan dalam pendataan anggota dan pembuatan laporan. Data-data anggota Posyandu dan segala peralatan yang mendukung kegiatan Posyandu disimpan terpisah di beberapa kader Posyandu, sehingga pengarsipan data kurang baik.

3. Pengarsipan data kurang baik, pengolahan data dan pembuatan laporan memakan waktu yang relatif lama dikarenakan peng-input-an data dan penyimpanan data masih dilakukan secara manual. Masih terjadinya 
kerangkapan dan kehilangan data yang diakibatkan hilangnya Kartu Menuju Sehat (KMS) sehingga mengharuskan pendataan ulang. Hal ini menyebabkan data/laporan menjadi tidak akurat, tidak fleksibel, tidak praktis dan sulit untuk dikerjakan.

4. Dengan penggunaan Sistem Informasi Posyandu, diharapkan memudahkan kader dalam melakukan pekerjaannya seperti pengarsipan data, pengolahan data, dan pembuatan laporan, serta mengurangi kerangkapan data Posyandu..

\section{Daftar Pustaka}

[1] Badrun KW, Penelitian Tindakan dan Penelitian Tindakan Kelas, Yogyakarta, 1998.

[2] Dadang M. Nasher, Data Badan Pemberdayaan Masyarakat dan Pemerintahan Desa, Bandung, 2012.

[3] Gondodiyoto, Audit Sistem Informasi+Pendekatan Cobit, Edisi Revisi, Mitra Wacana Media, Jakarta, 2007.

[4] Jogiyanto, Hartono, Analisis dan Desain Sistem Informasi: Pendekatan Terstruktur Teori dan Praktek Aplikasi Bisnis, Andi Offset, Yogyakarta, 2006

[5] O'Brien, James A, Introduction to Infarmation System, Boston-Mc. Graw Hill, 2007.

[6] Tim penyusun, Pedoman Umum Pengelolaan Posyandu,Kemenkes RI, Jakarta, 2011. 